\title{
0 artigo 285-A do Código de Processo Civil e o princípio da razoável duração do processo ${ }^{1}$
}

\author{
Eliane Demetrio ${ }^{2}$ \\ Prof. Ms. Denise M. W. de Paula Machado ${ }^{3}$
}

\begin{abstract}
Resumo
0 presente estudo visa analisar os requisitos para o julgamento liminar de improcedência dos casos repetitivos, ou seja, do art. 285-A do CPC, introduzido pela Lei $11.277 / 2006$, bem como analisar a sua consonância com os princípios constitucionais. Aborda os principais pontos divergentes na doutrina acerca dos requisitos de aplicação do art. 285-A. Verificou-se que o dispositivo em questão encontra-se em perfeita conformidade não só com os princípios constitucionais do processo, como também com 0 atual sistema processual civil, que prima pela celeridade. Por fim, conclui que com a finalidade de conferir primazia ao princípio da razoável duração do processo, o art. 285-A constitui-se em um importante instrumento para o julgamento sem dilações indevidas.
\end{abstract}

Palavras-Chave: Processo Civil; Art. 285-A do CPC; Duração Razoável do Processo.

\section{Introdução}

A demora na prestação da tutela jurisdicional malogra a satisfação dos direitos subjetivos, afronta a dignidade da pessoa humana e principalmente, desacredita o Poder Judiciário. Não é por outra razão, que o fator "tempo" se constitui em uma preocupação que permeia incessantemente o espírito do legislador ao elaborar as leis, visando assegurar a efetividade do processo.

Nesta esteira é que a Emenda Constitucional n. 45/2004 incorporou ao rol dos direitos e garantias fundamentais o direito à razoável duração do processo, assegurado a todos, quer no âmbito judicial ou administrativo, bem como os meios que garantam a celeridade de sua tramitação (art. 50, LXXVIII da Constituição Federal).

A partir de então, com o intuito de efetivar o referido princípio constitucional, 0 Congresso Nacional aprovou uma série de Leis Federais, que inaugurando uma seqüência de

\footnotetext{
${ }^{1}$ Este ensaio teve por referência Trabalho de Conclusão de Curso apresentado ao Curso de Direito da Universidade Estadual de Londrina, de autoria da primeira sob a orientação da segunda.

${ }^{2}$ Acadêmica do 50 ano matutino do curso de Direito da Universidade Estadual de Londrina.

${ }^{3}$ Mestre em Direito das Relações So ciais pela Universidade Estadual de Londrina.
} 
mini-reformas no Código de Processo Civil, visa contribuir com mecanismos que objetivam a celeridade processual e a efetividade jurisdicional.

Dentre essas leis, destaca-se a Lei 11.277 de 2006, que acrescentou o artigo 285-A ao Código de Processo Civil e que se constitui o objeto deste estudo, no qual se analisará os requisitos autorizadores deste instituto que permite ao magistrado liminarmente julgar improcedente a ação, sem a necessidade de citar o réu, bem como verificar a sua consonância com os princípios constitucionais do processo.

\section{Do julgamento liminar de improcedência dos casos repetitivos}

Pretende-se neste capítulo expor acerca dos requisitos para o julgamento liminar de improcedência dos casos repetitivos e de sua contribuição para a efetivação do direito fundamento previsto no inc. LXXVIII do art. 5o da Constituição Federal do Brasil.

Eis 0 artigo em questão:

Quando a matéria controvertida for unicamente de direito e no juízo já houver sido proferida sentença de total improcedência em outros casos idênticos, poderá ser dispensada a citação e proferida sentença, reproduzindo-se 0 teor da anteriormente prolatada.

$\S 1$ ㅇ. Se 0 autor apelar, é facultado ao juiz decidir, no prazo de 5 (cinco) dias, não manter a sentença e determinar o prosseguimento da ação.

$\S 2$ a Caso seja mantida a sentença, será ordenada a citação do réu para responder ao recurso.

Da interpretação do dispositivo, verifica-se portanto, que uma vez presentes os requisitos o magistrado julgará improcedente de plano o pedido do autor, sem a oitiva da parte contrária, ou seja, haverá um julgamento liminar de mérito.

\section{Requisitos}

0 julgamento liminar de improcedência tem por escopo solucionar o problema da multiplicação dos casos repetitivos que contemporaneamente abarrotam o Poder Judiciário, resultando na notória morosidade desse Poder.

Nesta vertente é o entendimento de Cássio Scarpinella Bueno (2006, p. 53), que ao tratar das "demandas de massa" assevera: 
0 art. 285-A deve ser entendido como uma forma de debelar o que a prática judiciária costuma denominar, muitas vezes, de 'processos repetitivos', em que 0 que se discute basicamente é uma mesma tese jurídica aplicada a uma mesma situação fática inconteste ou, quando menos, que não desperta maiores dúvidas ou indagações das partes e do próprio magistrado. Uma situação fática que não aceita ou não apresenta peculiaridades.

Portanto, o que se verifica atualmente é uma multiplicação de ações que veiculam a mesma tese jurídica (mesmos fatos e fundamentos jurídicos), ou seja, certa situação fática atinge centenas de pessoas, que ingressam em juízo postulando o reconhecimento de seu direito. Logo, em tais casos há o que o se denomina de "demandas de massa" e que exigem pois, a mesma solução, observando-se desse modo o princípio da isonomia.

A prática forense revela que diante dessa hipótese, as petições iniciais propostas têm como base os mesmos argumentos jurídicos, pois são resultantes da mesma situação de fato; as contestações em contrapartida, também possuem o mesmo teor e portanto, as sentenças prolatadas serão idênticas para todos esses casos repetitivos, contendo apenas adaptações diante de cada caso concreto, alterando-se os nomes das partes envolvidas e 0 número do processo. Enfim, com a multiplicação das "demandas de massa" há a proliferação - e difusão- dos vulgos "modelos" de petições iniciais.

A título de exemplo de "demandas de massa" são as ações propostas contra 0 Estado, tais como as de natureza tributária e previdenciária, as ações de servidores públicos e consumidores.

É neste panorama que se insere o artigo 285-A do Código de Processo Civil, destinado a solucionar os casos repetitivos em que desde o seu nascedouro já se saberá o seu resultado final, se atendidos os requisitos para a aplicabilidade, que são: a) matéria controvertida unicamente de direito e b) no juízo, já houver sido proferida sentença de total improcedência em outros casos idênticos.

\section{Definição de "casos idênticos"}

Como bem se expôs no tópico acima, o intuito do art. 285-A é solucionar de maneira célere os casos repetitivos, expressos pela lei como "casos idênticos".

Muito embora o texto de lei menciona "casos idênticos" como requisito de aplicabilidade, esse deve ser interpretado como casos que veiculam a mesma tese jurídica, 
ou seja, mesmo fundamento jurídico, com questões predominantemente de direito, não restando dúvida quanto à veracidade das alegações afirmadas pelo autor.

Luiz Rodrigues Wambier, Teresa Arruda Alvim Wambier, José Miguel Garcia M edina (2006, p.68) ensinam que:

[... Por 'casos idênticos' haver-se-á e entender aqueles em que se repitam as mesmas circunstâncias fáticas e jurídicas, que em nada se difiram numa e noutra ação. Para que se identifique tal identidade, não basta que tais ações tenham 0 mesmo pedido e mesma causa de pedir. Mais que isso, os fundamentos jurídicos integrantes da causa de pedir e do pedido de tais ações também deve ser idêntico (grifos dos autores).

Interpretar literalmente o texto de lei conduziria à impossibilidade de aplicação do art. 285-A, por razão de que os "casos idênticos" pressupõem a identidade dos três elementos da ação: partes, causa de pedir e pedido, de acordo com 0 art. 301, §2 do CPC, resultando assim na ocorrência de litispendência ou coisa julgada, devendo o segundo processo ser extinto sem o julgamento do mérito.

Outrossim, revela Fernando da Fonseca Gajardoni (2007,p.119) que é de extrema importância que se identifique a identidade do fundamento jurídico dos casos repetitivos, pois o magistrado ao aplicar o art. 285-A, deverá reproduzir o teor (no caso os fundamentos jurídicos) da sentença paradigma. Deste modo, se o caso em apreço pelo juiz apresentar tese jurídica nova, "a sentença paradigma não poderá ser repetida por não se subsumir a integralidade dos fundamentos jurídicos apresentados". Porém, ressalva o mencionado autor que, a apresentação de novos argumentos que somente visam reforçar a tese jurídica já rechaçada pelo juízo não constitui óbice para a aplicação do art. 285-A do CPC 4 .

Por fim, verifica-se que é unânime entre os doutrinadores a necessidade de haver no juízo mais de dois casos com mesma tese jurídica já julgada improcedente, para que um terceiro posso ser julgado com base no art. $285-\mathrm{A}^{5}$.

4 Em sentido contrário: Luiz Rodrigues Wambier, Teresa Arruda Alvim Wambier, José Miguel Garcia Medina (2006, p.68), para quem "na ação subseqüente não poderá haver nenhum argumento novo que deva ser apreciado pelo juiz".

5 Nesse sentido: Fernando da Fonseca Gajardoni (2007, p.120); Misael Montenegro Filho (2008, p.353), Luiz Rodrigues Wambier, Teresa Arruda Alvim Wambier, José Miguel Garcia M edina (2006, p.67). 
M atéria controvertida unicamente de direito

Para que o magistrado possa proferir sentença de improcedência prima facie, é preciso que a "matéria controvertida seja unicamente de direito".

Primeiramente, cumpre esclarecer que a matéria torna-se controvertida a partir do momento que a parte contrária impugna algum fundamento de fato ou de direito (ou seja, um ponto) afirmado pelo autor. Deste modo, com a impugnação, o ponto torna-se controvertido, surgindo assim uma questão. Ocorre que, como não há a manifestação do réu diante da não necessidade de sua citação com a aplicação do dispositivo em comento, não há como haver uma questão, ou seja, matéria controvertida.

Portanto, como ressalvam Nelson Nery Jr. e Rosa M. A. Nery (2007, p. 555), ao esclarecerem que "onde está escrito ' matéria controvertida' deve ler-se 'pretensão que já tenha sido controvertida em outro processo e julgada improcedente pelo mesmo juízo" (grifos dos autores).

Constitui pressuposto para a aplicação do art. 285-A que pretensão verse somente sobre questões de direito, conforme Teresa Arruda Alvim Wambier e Luiz Rodrigues Wambier, que nesse caso "são verdades jurídicas, que seguem sendo verdades jurídicas, apesar de haver pequenas alterações no plano dos fatos" (2007, p. 40).

Logo, verifica-se que nas hipóteses em que o dispositivo (art. 285-A) incidirá, haverá uma predominância das questões jurídicas sobre possíveis questões de fato, pois impossível dissociar o direito do mundo fático. Ademais, as questões de fato presentes nas "demandas de massa" (casos repetitivos) são indiscutíveis e não geram controvérsias, não sendo preciso, pois, a comprovação do ponto alegado (além da prova documental acostada na exordial), requerendo do magistrado apenas uma apreciação das teses jurídicas apresentadas.

Nesta vertente, Cássio Scarpinella Bueno (2006, p. 75), ao tratar da predominância das questões de direito, para quem a:

questão de fato é alheia a qualquer questionamento, a qualquer dúvida, ela é padronizada ou, quando menos, padronizável; ela, a situação de fato, não traz em si, maiores questionamentos quanto a sua existência, seus contornos e seus limites. 0 que predomina, assim, é saber qual o direito aplicável sobre aqueles fatos que não geram dúvidas, que não geram controvérsias entres as partes e perante 0 juiz. 
Ademais, como bem salienta Humberto Theodoro Jr. (2007, p.16), a incidência do dispositivo sobre as questões predominantemente de direito legitima o julgamento liminar de improcedência, pois não irá resultar em nenhum prejuízo para o réu, posto não haver controvérsias acerca das questões de fato.

Disto se extrai que se a pretensão versar predominantemente sobre questões de fato e portanto requerer produção de prova, o magistrado não poderá utilizar-se do dispositivo em tela, devendo determinar o prosseguimento regular do feito, sob pena de violar o princípio do contraditório e da ampla defesa.

Decisões proferidas no mesmo juízo

O juízo se constitui em um órgão jurisdicional que possui competência para processar e julgar os litígios nos limites de uma determinada circunscrição territorial. "Uma comarca ou seção judiciária, pode ser dotada de vários juízos, unidades jurisdicionais, distribuídas em varas" (CAM BI, 2006, p. 58).

Conforme uma interpretação literal do artigo 285-A do CPC, verifica-se que o magistrado se valerá da sentença paradigma proferida no mesmo juízo que atua, ou seja, na mesma Vara que se processa a ação em apreciação. 0 dispositivo não faz referência à autoria da sentença que servirá de base para o julgamento liminar de improcedência, ou seja, se foi proferida pelo juiz titular, substituto ou auxiliar. Logo, desde que a sentença tenha sido proferida no mesmo juízo em que tramita a ação, o juiz (seja titular, substituto ou auxiliar) poderá julgar com fulcro no art. 285-A, sendo somente vedado à utilização de sentenças paradigmas proferidas em outro juízo (Vara) ${ }^{6}$.

Como ressalta Scarpinella Bueno (2006, p.78), o “'empréstimo' de precedentes no mesmo plano judicante, [...], deve ser evitado a todo custo, sob pena de inversão lógica da jurisprudência, que pressupõe [..], decisões constantes dos Tribunais, em nome da maior segurança jurídica".

Mister se faz aludir a Fernando da Fonseca Gajardoni (2007, p. 114), ao ressaltar que, ao possuir o juízo o mesmo entendimento acerca de certa questão de direito,

6 Neste sentido, Dorival Renato Pavan (2007, p. 88): “como a lei se refere a juízo, significa entender que está se tratando do órgão jurisdicional, não importando que ali esteja atuando o juiz titular, auxiliar ou seu substituto legal. Basta que no juízo outros feitos idênticos tenham recebido uma mesma solução, para legitimar a sentença de improcedência [...]" (grifo do autor). 
possibilitará aos jurisdicionados prever a posição adotada pela unidade jurisdicional em que tramita a ação, conferindo assim, segurança jurídica às questões já juridicamente decididas naquela Vara, desmotivando por conseguinte, a propositura de novas demandas com a mesma tese jurídica .

Ressalte-se que devido ao princípio do livre convencimento motivado, é plenamente possível que dentro de um mesmo juízo, em que jurisdicionam um juiz titular e um auxiliar, haja entendimentos divergentes sobre o mesmo tema, ou seja, alguns casos sendo liminarmente julgados improcedentes e outros não. Nesses casos, como bem argumenta Gajardoni (2007, p.115), não há uma posição adotada pelo juízo, não sendo assim possível a aplicação do artigo 285-A por não haver uma previsibilidade do que se decide neste juízo. Entender de maneira contrária, importaria na expressa violação do princípio constitucional da isonomia, previsto no art; 5o, caput da Constituição Federal.

\section{Da sentença paradigma}

Da conformidade com o entendimento dos tribunais superiores

Como não bastasse que a sentença paradigma tenha sido proferida pelo mesmo juízo, constitui um requisito implícito e de acordo com a sistemática processual civil, que a sentença paradigma deva estar em consonância com os julgamentos dos tribunais superiores, principalmente com os do Superior Tribunal de Justiça e do Supremo Tribunal Federal e com as súmulas vinculantes. Deste modo, estar-se-á verdadeiramente atingindo a finalidade do dispositivo: racionalizar o julgamento dos casos repetitivos, de maneira desburocrática e célere, além de melhor atender à atual sistemática processual civil.

Agir de maneira contrária, ou seja, utilizar-se o magistrado de uma sentença paradigma que esteja em dissonância com o entendimento dos Tribunais somente importará na interposição de inúmeros recursos, ocasionando um "estrangulamento definitivo do sistema recursal" (BUENO, 2006, p. 61). É enfim, atentar contra a própria atividade jurisdicional, bem como contra o direito fundamental da razoável duração do processo ${ }^{7}$.

7 Também o entendimento de Teresa Arruda Alvim Wambier e Luiz Rodrigues Wambier (2007, p. 42) quando tratam da questão da convicção do juiz ser conforme ao entendimento dos Tribunais, quando houver jurisprudência dominante ou súmula. 
Justifica-se a adequação da sentença paradigma proferida pelo juiz de primeira instância ao entendimento consolidado pelos Tribunais Superiores, pela conseqüência jurídica que tal atitude implicará, de maneira que atenda às exigências do atual sistema recursal.

A consonância da sentença de primeiro grau de jurisdição com a Súmula do STJ ou do STF importará no não recebimento da apelação pelo próprio juiz da causa, perante o qual 0 recurso é interposto, conforme previsão do artigo 518, §3ำ do CPC. Ademais, não estará sujeita ao reexame necessário (art. 475, §3ํ do CPC).

Não bastassem, por força do art. 557 do CPC, as súmulas e jurisprudência dominante dos Tribunais Superiores constituem-se em outra modalidade apta a impedir o recurso, uma vez que o relator negará seguimento ao recurso que estiver em "confronto com súmula ou jurisprudência dominante do respectivo Tribunal, do Supremo Tribunal Federal, ou de Tribunal Superior". E mais, desacolher de plano e monocraticamente possível agravo da decisão que não recebeu a apelação (art. 557, §1ํ do CPC).

\section{Da sentença paradigma de total improcedência}

Conforme se extrai do texto de lei, o julgamento liminar da ação somente poderá ser proferido nos casos de desacolhimento do pedido. Outro não poderia ser, uma vez que o julgamento liminar de procedência da lide violaria incontestavelmente o princípio do devido processo legal (e seus princípios decorrentes- contraditório e ampla defesa), diante da impossibilidade da parte contrária manifestar-se com relação ao pedido do autor, pelo fato de não ter sido chamado a se defender em juízo.

Diante desta afirmação, o magistrado não poderá julgar com base no art. 285-A quando os casos idênticos não tiverem sido julgados totalmente improcedentes, pois pelo fato do réu não ter sido citado para apresentar suas teses e assim poder influir no convencimento do juiz, a sentença deve ser "integralmente favorável ao réu” (CAM BI, 2006, p. 62).

Portanto, com a verificação de plano da insubsistência da pretensão do autor sem sequer ouvir ao réu constitui, além de respeito ao princípio da razoável duração do processo, respeito ao princípio da economia processual, uma vez que com a medida se evita gastos desnecessários com a contratação de advogado e os conseqüentes incômodos decorrentes 
do tramite da ação, bem como contribui para diminuição de gastos para a própria justiça e com o acúmulo de trabalho que abarrota o Poder Judiciário.

Da distinção entre julgamento com base no art. 285-A e do julgamento antecipado da lide

Conforme se extrai do artigo 330 do CPC, após a citação do réu, o juiz julgará imediatamente a lide quando "I. a questão de mérito for unicamente de direito, ou, sendo de direito ou de fato, não houver necessidade de produzir prova em audiência e II. quando ocorrer revelia" Destaca-se que tal julgamento poderá ser tanto de procedência quanto de improcedência da pretensão, diante do exaurimento da cognição. Ademais, diante de tais circunstancias, o magistrado deverá julgar conforme 0 art. 330.

Já o julgamento prima facie (art. 285-A do CPC), apesar de também possuir como pressuposto matéria unicamente de direito, não se confunde com o julgamento com base no art. 330, I do CPC, uma vez que o magistrado somente poderá (faculdade) julgar liminarmente improcedente a lide sem a citação do réu, se houver no juízo outros casos que foram julgados improcedentes em razão da tese jurídica veiculada ter sido a mesma, portanto, já estão pacificados no juízo. Diante desta faculdade, o magistrado não está vinculado às decisões de improcedência proferidas anteriormente no juízo, podendo assim, motivadamente, no exercício do juízo de valor diante de cada caso concreto, modificar seu entendimento anterior ou ainda entender que a questão não é unicamente de direito, determinando produção de provas para melhor formar seu convencimento, deixando deste modo de aplicar 0 art. 285- $A^{8}$.

Do recurso contra o julgamento liminar de improcedência dos casos repetitivos e do juízo de retratação

Tendo o magistrado julgado liminarmente improcedente o mérito da pretensão do autor (logo, sentença de mérito- art. 269, I, CPC), esse poderá interpor recurso de apelação contra a referida sentença dentro do prazo de 15 dias; sendo facultado ao juiz exercer 0 juízo de retratação, no prazo impróprio de 5 (cinco) dias (art. 285-A, §1으 do CPC),

8 Na mesma linha, Cássio Scarpinella Bueno (2006, p. 80), Nelson Nery Jr. e Rosa M .A. Nery (2007, p. 555). 
determinando assim, o prosseguimento regular do processo e consequentemente, ficando prejudicado o recurso.

Destaca-se que no exercício do juízo de retratação, o magistrado não poderá rever sua decisão no sentido de julgar procedente ou parcialmente procedente o pedido, sob pena de violar as garantias constitucionais do devido processo legal, da ampla defesa e contraditório.

Todavia, caso entenda o juiz manter a sentença de improcedência liminar, deverá o réu ser "citado" para responder o recurso de apelação dentro do prazo de 15 dias (art. 285A, $2^{\circ}$ ) , assegurando nesta oportunidade o contraditório.

No conteúdo do recurso de apelação, o autor deverá "demonstrar a razão pelo qual 0 art. 285-A não poderia ter sido aplicado no caso concreto" (BUENO, 2006, p. 82), ou seja, deverá demonstrar o não enquadramento do seu caso à decisão paradigma; ausência de identidade fática ou não conformidade da sentença de primeiro grau com o entendimento dos tribunais superiores.

0 réu, após "citado", tem o direito de apresentar sua defesa, no caso, suas contrarazões de recurso.

A maioria dos doutrinadores entende correto o uso do termo "citação" do réu, sob o fundamento de que "toma conhecimento da existência da demanda somente após a sentença" (CAMBI, 2006, p. 65; M ONTENEGRO FILHO, 2008, p. 353, N.NERY JR, R.A.NERY, 2007, p. 556).

A citação consiste no "ato pelo qual se chama a juízo o réu ou o interessado a fim de se defender" (art.213,CPC), possuindo como instrumentos de defesa a contestação e exceções processuais, além de poder opor reconvenção, que se constitui em uma das formas de reposta do réu. A partir da realização da citação válida, se operam seus efeitos: tornar prevento o juízo, induzir litispendência, tornar litigiosa a coisa, constituir em mora o devedor e interromper a prescrição (art. 219).

Importante salientar que apesar da utilização do termo "citação", no caso do artigo 285-A, ela possui a função de "comunicar o réu da apresentação das contra- razões" e não propriamente de se defender (contestando), pois a reposta do réu é mais ampla que as contra-razões. Assim, ela não operará seus efeitos previstos no art. 219 do CPC, tendo em 
vista que a formação completa da relação jurídica processual ocorre em segundo grau de jurisdição.

Na mesma linha, Cássio Scarpinella Bueno (2006, p. 86):

Evidentemente que a cláusula do art. 285-A deve, aqui, ser entendida em termos, dando-se ciência ao réu de que ele está sendo citado não para contestar, mas para, a partir daquele instante procedimental, acompanhar o feito e apresentar as contra-razões ao recurso de apelação do autor (grifos nossos).

Partindo desta premissa, o fato do réu ser "citado" apenas para responder ao recurso, as suas contra-razões não poderiam ser recebidas como se fossem contestação, uma vez que o réu deve se ater a rebater os argumentos do recurso de apelação. Deste modo, a sua manifestação limita-se à existência dos pressupostos recursais e a correta aplicação do art. 285-A do CPC (CAM BI, 2006, p. 67; M ONTENEGRO FILHO, 2008, p. 353).

Entender de modo contrário resultaria em um "evidente desequilíbrio ao princípio da isonomia e das garantias do contraditório e ampla defesa", pois caso as contra-razões tivessem natureza de contestação, geraria um manifesto prejuízo ao réu que apenas se manifesta em sede recursal, ocorrendo para ele a supressão de um grau de jurisdição, enquanto 0 autor possui duas instâncias para alegar sua tese jurídica (CAM BI, 2006, p. 67).

Deste modo, considerando que a "citação" (no sentido de comunicação) do demandado é somente para responder o recurso, uma vez anulada a sentença e consequentemente a citação, por ser ato posterior àquele, será concedida a oportunidade para que o réu, após novamente citado, exerça de modo pleno a ampla defesa, apresentando contestação e exceções ou reconvenção ${ }^{9}$.

Dessa linha de raciocínio resulta a conseqüência de que o Tribunal ao julgar 0 recurso de apelação deve se ater à verificação da presença dos requisitos autorizadores do julgamento liminar de improcedência, sendo vedado a reforma da sentença de primeiro grau para reconhecer a procedência total ou parcial do pedido do autor, sob pena de ofensa aos princípios do contraditório e ampla defesa, uma vez que o réu não teve oportunidade de influenciar no convencimento do magistrado em sede de primeiro grau. Assim, fica o

9 Neste sentido, Fernando da F. Gajardoni (2007, p. 125): “Caso a sentença liminar seja cassada pelo Tribunal por impossibilidade de utilização do art. 285-A do CPC, a citação para as contra-razões, por ser ato subseqüente à sentença neste novo regime, automaticamente restará prejudicada" (art. 248 do CPC). Assim como Cássio Scarpinella Bueno (2006, p.87) (grifo nosso). 
Tribunal impossibilitado de aplicar o art. 515, §30 do CPC diante da sentença que julgou com base no art. 285-A (CAMBI, 2006, p.68) .

\section{0 julgamento liminar de improcedência dos casos repetitivos e os princípios constitucionais do processo civil}

\subsection{Artigo 285-A e o princípio da isonomia}

Considerando que a finalidade do artigo 285-A do CPC é de racionalizar o julgamento das "demandas de massa", ou seja, dos casos repetitivos (aqueles que veiculam a mesma tese jurídica) verifica-se que a supramencionada regra veio conferir o efetivo tratamento isonômico aos jurisdicionados que se encontram diante da mesma situação jurídica, garantindo-se assim, o respeito ao princípio da isonomia.

Nesta mesma esteira, enfatiza com argúcia Cássio Scarpinella Bueno (2006, p. 191) que a regra do artigo 285-A é :

[...] salutar que garante que, diante do mesmo fato, deve ser prolatado, na brevidade possível, o mesmo resultado jurídico, dispensando aos litigantes- e, em especial, aos variados autores-, desta maneira, escorreito tratamento isonômico. É, neste sentido, regra que racionaliza o proferimento de julgamentos uniformes para os mesmos casos ('casos idênticos') na exata medida em que eles sejam distribuídos para os mesmos juízos. (grifos do autor)

Prossegue ainda o supracitado autor pontificando que caberá aos Tribunais dos respectivos juízos "uniformizarem, gradativamente, qual é e qual não é o entendimento prevalecente", diante da possibilidade de um outro juízo ter entendimento diverso sobre a mesma tese jurídica veiculada nos casos repetitivos e assim, não aplicar a regra do art. 285A.

Todavia, muito embora o texto do dispositivo em tela se refira a possibilidade de julgamento liminar face à existência no juízo de sentenças precedentes de improcedência sobre "casos idênticos", importante ressaltar que, para a presente regra alcançar sua finalidade plena, convém que o magistrado baseie sua decisão conforme o entendimento dos Tribunais superiores, conferindo além de maior celeridade ao trâmite processual,

10 Em sentido contrário, a favor da aplicação do art. 515, 30 do CPC: Nelson Nery Jr. e Rosa M. A. Nery (2007, p.556). 
respeito pleno ao princípio da isonomia, uma vez que as jurisprudências e súmulas dos Tribunais superiores possuem efeito uniformizante.

\subsection{Artigo 285-A e o princípio da segurança jurídica}

O princípio da segurança jurídica, conforme lição de Cássio Scarpinela Bueno (2006, p. 193), consiste na "previsibilidade do comportamento a ser adotado pelo magistrado em caso concreto".

De fato, o ordenamento jurídico tem como função precípua orientar a conduta humana, no sentido de possibilitar aos cidadãos o prévio conhecimento do que podem ou não fazer, considerando as eventuais conseqüências imputadas a seus atos.

Não bastasse, a regra do art. 285-A assegura o respeito ao princípio da segurança jurídica na medida em que constitui comando constitucional o dever do magistrado fundamentar suas decisões (art. 93, IX, CF). Logo, em que pese à exigência da reprodução do teor da sentença paradigma ao caso concreto, essa não satisfaz os requisitos da sentença por si só, devendo o magistrado a cada caso novo que julgar com base no art. 285-A, demonstrar motivadamente a razão de ter considerado os "casos idênticos". (GAJARDONI, 2007, p. 112)

A segurança jurídica é ainda mais expressiva quando se constata que a decisão do magistrado ao aplicar o art. 285-A teve por base a jurisprudência ou súmula do Tribunal Superior, pois seus entendimentos consolidados tendem a uma maior estabilização sobre o direito aplicável ao caso concreto; conforme se depreende da lição de Cássio Scarpinela Bueno (2006, p. 58) para quem, "esta maior estabilidade das decisões consolidadas em um ou em outro sentido perante os Tribunais Superiores reflete maior segurança jurídica e, com isto, potencializa a isonomia entre os mais variados jurisdicionados".

\subsection{Artigo 285-A e o princípio do direito de ação}

0 art. 5ำ da CF estabelece que "a lei não excluirá da apreciação do Poder Judiciário, lesão ou ameaça a direito". Fica assim consubstanciado o princípio ao acesso à justiça a todos os cidadãos indistintamente. 
Ressalte-se que não basta apenas que o Estado preste a tutela jurisdicional, mais que isso, esta prestação deve ser adequada, sob pena de esvaziar-se seu sentido. Neste contexto é que se pode considerar que uma prestação jurisdicional tardia não é adequada e, portanto, injusta.

0 direito de ação consiste no instrumento que 0 jurisdicionado possui à disposição para acionar o Poder Judiciário com o intuito obter um resultado, ou seja, uma solução de determinado conflito de interesse. Todavia, tal acesso ao Judiciário não Ihe garante resultado favorável (BEDAQUE, 1999, p. 157).

Assim, considerando a autonomia e abstração do direito de ação, mesmo quando a parte recebe uma sentença que seja oposta às suas pretensões, ela exerceu o direito de ação em sua plenitude, uma vez que o Estado-juiz forneceu uma resposta ao seu pedido, resposta essa desvinculada da existência, ou não, do direito material alegado pelo seu titular.

Disso se extrai que o artigo 285-A não viola o princípio do direito de ação, uma vez que o Estado-juiz respondeu ao pleito do autor initio litis, pois se verificou de plano que seu pedido era improcedente, em razão da existência de outros "casos idênticos" no juízo também julgados improcedentes.

Não bastasse, Cássio Scarpinella Bueno (2006, p.194) pontifica que a regra do art. 285-A não "impede a instauração regular do processo", pelo contrário, ele apenas "legitimamente" difere a necessidade de citação do réu para o caso de interposição de recurso contra a sua sentença, ocorrendo nesse momento processual o exercício do contraditório. Em suas palavras, "há, destarte, escorreito exercício do direito de ação em regular processo que se forma gradativamente, como já ocorre nos casos de indeferimento liminar de qualquer petição inicial (art. 296 do CPC)" (grifo nosso).

\subsection{Artigo 285-A e o princípio do devido processo legal}

O princípio do devido processo legal constitui-se em um "supra princípio", ou seja, um princípio fundamental do qual decorrem todos os demais princípios (contraditório, ampla defesa, motivação, etc.). Segundo Misael M ontenegro Filho (2007, p. 26), tal princípio é nada mais que uma "exigência de que o processo deva ser conduzido de acordo com a 
forma prevista em lei, não se admitindo a prática de atos- em prejuízo a uma das partes- não previstos em norma legal ou por ela vedados".

Como manifestação do due process of law, são assegurados aos litigantes 0 contraditório e a ampla defesa, com os meios e recursos a ela inerentes (art. 5, LV, CF).

Como bem assevera Rui Porta Nova (2005, p. 163), o exercício do princípio do contraditório inicia-se antes mesmo da citação e não termina com a prolação da sentença, uma vez que já na elaboração da petição inicial a "idéia de bilateralidade tem seus reflexos, por igual a sentença, com a necessidade da motivação, é informada por este princípio".

Já o princípio da ampla defesa se constitui em uma conseqüência do contraditório, pois "além do direito de tomar conhecimento de todos os termos do processo (princípio do contraditório), a parte também tem o direito de alegar e provar o que alega e [...] de não se defender" (NOVA, 2005, p. 125). Outrossim, quando a parte exercita seu direito de defesa, 0 faz com ampla liberdade.

Em que pese à existência de entendimentos diversos, verifica-se que 0 artigo 285-A não viola o princípio constitucional do contraditório e ampla defesa, e portanto, do devido processo legal, mas ao contrário, o dispositivo "por estar em conformidade com o novel princípio da tempestividade da tutela jurisdicional (art. 5ạ, LVXXVIII, CF), vem ao encontro dos anseios por justiça célere" (GAJARDONI, 2007, p. 112).

Primeiramente, considerando o supracitado entendimento de Rui Porta Nova, vê-se que 0 art. 285-A possibilita que 0 autor ao elaborar sua petição inicial exerça de maneira ampla o contraditório, na medida em que dela constará sua tese jurídica com o intuito de influenciar no convencimento do juiz. Não bastasse, com a prolação de sentença liminar de improcedência, ao autor ainda é garantido o exercício do contraditório no "sentido de poder influenciar, legitimamente, a convicção do magistrado com vistas à reforma da sentença" (BUENO, 2006, p. 196). Neste caso, deverá o autor argumentar no sentido de que seu caso não era idêntico à sentença paradigma, ou que havia tese jurídica nova não constante da sentença paradigma, ou que o seu caso não era exclusivamente de direito, assim, a sentença de improcedência seria cassada, retornando os autos para seu regular prosseguimento em primeiro grau.

Segundo, quanto ao réu, verifica-se que o exercício do contraditório não Ihe foi suprimido, mas sim diferido ou postergado. Tal assertiva encontra justificativa no fato de no 
âmbito de primeiro grau ter sido rejeitada de plano a pretensão do autor, por já ter o juízo convicção formada de que sua tese jurídica é improcedente considerando outros "casos idênticos" para fundamentar sua decisão. Esta sentença de improcedência por si só já caracteriza que, implicitamente, o réu teve acolhido seu pedido de rejeição ao pleito do autor, resultando-lhe em uma vantagem sem ao menos ter sido integrado ao processo (BUENO, 2006, p. 85). Ademais, o réu será chamado a participar da relação jurídica processual apenas quando houver interposição de recurso contra a sentença que julgou liminarmente improcedente o pedido do autor.

Portanto, não há violação ao princípio do contraditório, pois caso o Tribunal reverta a situação que Ihe era até então favorável, obrigatoriamente ser-Ihe-á garantido o exercício pleno da defesa em primeiro grau de jurisdição. Vê-se claramente que na hipótese do art. 285-A, o contraditório é "diferido com relação à possibilidade de rejeição liminar da inicial e eventual juízo de retratação pelo juízo sentenciante" (BUENO, 2006, p. 84).

Outrossim, deve-se apreciar a questão sob o enfoque da ampliação do acesso à justiça, e principalmente, valorizando o princípio da economia processual, máxime definidora de que sem prejuízo não há nulidade. Na hipótese da regra do art. 285-A, em primeira instância não houve prejuízo algum para o réu, ao contrário, apenas obteve resultado positivo (vantagens) com a sentença liminar de improcedência e muito menos prejuízos para o autor, que obteve o resultado final (ainda que negativo) do processo sem delongas, não havendo que se cogitar, portanto, nulidade do processo pelo fato de não ter sido o réu citado.

\subsection{Artigo 285-A do código de processo civil como instrumento para a efetivação do princípio da razoável duração do processo}

A grande e atual preocupação do legislador infraconstitucional é o fator tempo, que tem sido o condutor das reformas processuais com vistas à criação de instrumentos que asseguram a tutela tempestiva e adequada dos direitos, permitindo assim que haja uma tramitação mais célere e eficiente dos processos.

De igual sorte, Cintra, Dinamarco e Grinover (2006, p. 93) ao afirmarem que "a garantia da prestação jurisdicional sem dilações indevidas integram o conjunto de garantias conhecidas como devido processo legal- porquanto justiça tardia não é verdadeira justiça". 
Mesmo antes da Emenda Constitucional №45/2004, Cruz e Tucci (1999, p. 260) defendia que o direito à tutela tempestiva, como corolário do princípio do devido processo legal, constituía-se em um preceito fundamental, possuindo assim, aplicação imediata.

Deste modo, verifica-se, indubitavelmente, que a intenção do legislador infraconstitucional ao instituir o artigo 285-A do Código de Processo Civil é de, atendendo aos reclamos sociais, proporcionar uma maior racionalização e celeridade à prestação da tutela jurisdicional, conferindo efetividade ao disposto no art. 50, inciso LXXVIII da CF, à medida que entrega de pronto a tutela jurisdicional ao autor, dispensando-se de modo racionalmente justificável a citação do réu, que se mostra desnecessária diante da convicção já formada do magistrado em conseqüência às teses jurídicas repetitivas (que veiculam somente matéria de direito) que em outros processos já foram exaustivamente debatidas (BUENO, 2006, p. 69).

Com o julgamento liminar, mesmo que de improcedência, o pronunciamento judicial cumpre com sua missão de compor a lide tempestivamente, gerando o sentimento de satisfação aos jurisdicionados e confiança ao Poder Judiciário. Enfim, todos são beneficiados, pois "mesmo aquele que sai derrotado não deve lamentar-se da pronta resposta do Judiciário, sob o prisma psicológico, o possível e natural inconformismo é, sem dúvida, mais tênue quando a luta processual não se prolonga durante muito tempo" (CRUZE TUCCl, 1999, p. 236).

Ademais, para que o resultado de um processo seja considerado útil e adequado, a decisão final deve ser prolatada dentro de um prazo razoável, compatível com a natureza do objeto em litígio. Neste contexto encontra-se conforme a regra do artigo 285-A do CPC, pois considera os casos que contém exclusivamente questões de direito, julgados improcedentes em outros casos idênticos em primeira instância e/ou são contrários ao entendimento dos Tribunais Superiores, devendo assim serem julgados com rapidez.

Ensina sabiamente, José Roberto dos Santos Bedaque, que a "eficiência da justiça civil, como valor a ser defendido e preservado, encontra-se amparo no princípio constitucional da efetividade da tutela jurisdicional e constitui elemento essencial do Estado de Direito" (1999, p. 159).

A efetividade constitui uma garantia fundamental do processo, uma vez a para a atividade jurisdicional do Estado alcançar um resultado útil, deve ser prestada com eficiência 
e rapidez, garantia essa que se amolda perfeitamente no objetivo do art. 285-A do CPC: prestar uma tutela jurisdicional liminarmente, ainda que desfavorável à pretensão do autor.

Outrossim, é evidente a intenção do legislador em conferir prevalência ao princípio da razoável duração do processo na elaboração da Lei 11.277/2006 que criou o instituto do julgamento liminar de improcedência dos casos repetitivos, conforme bem se na exposição dos motivos da mencionada lei:

Sob a perspectiva das diretrizes estabelecidas para a reforma da Justiça, faz-se necessária a alteração do sistema processual brasileiro com o escopo de conferir racionalidade e celeridade ao serviço de prestação jurisdicional, sem contudo, ferir o direito ao contraditório e à ampla defesa.(LUIZ FUX, 2006, p. 27) (grifo nosso).

Ao manifestar-se acerca da finalidade do instituto, a doutrina majoritária entende que o escopo primordial do artigo 285-A do Código de Processo Civil é conferir efetividade ao princípio constitucional da razoável duração do processo. (CAM BI, 2006, p. 53; BUENO, 2006, p. 53)

Portanto, de acordo com o que está explicitado no Projeto e com a doutrina majoritária, a recente Lei 11.277/2006 visa racionalizar o julgamento de casos repetitivos através da dispensa da citação em primeira instância. Agindo desta maneira, conferir-se-á maior celeridade ao processo, alcançando por sua vez, o preceito constitucional fundamental que assegura a todos os cidadãos a razoável duração do processo.

\subsection{Da supremacia dos princípios}

Os princípios têm precípua responsabilidade de organizar todo o sistema jurídico e atuar como liame de todo o conhecimento jurídico com fim de alcançar os resultados eleitos.

Crucial relembrar que "princípio não revoga princípio; antes se harmonizam, abrindo espaço para a aplicação da justiça no caso concreto, mediante outro princípio" (LEITE, 2008, p. 59).

Convém salientar, outrossim, que a interpretação dos princípios não é estática e imutável, ao contrário, é dinâmica e evolui com o tempo. Os anseios sociais se modificam constantemente e os valores que a nação elege como atual e importante é o que definirão 
quais serão os resultados escolhidos e que devem preponderar. A partir daí é que conferirse-á "um novo enfoque à observância dos princípios [...] mediante a adequação da técnica processual às regras de direito material" (LUCON, 1999, p. 94). Com efeito, o que se vê contemporaneamente é a adequação do sistema processual brasileiro (através de inúmeras Reformas) à atual mazela que aflige tanto o âmbito judicial e administrativo: a morosidade.

Justamente neste contexto é que se insere a Lei 11.277/06 que acertadamente respeita a técnica de prevalecimento de princípios de acordo com a ponderação de valores sociais atuais.

Diante de tais considerações, enfatiza-se que o exercício do princípio do contraditório e consequentemente, do devido processo legal, nos casos em que há a aplicação da regra do art. 285-A do CPC, não são excluídos e sim, como já se mencionou, são diferidos, postergados na medida em que o dispositivo é expresso em admitir, além do juízo de retratação pelo magistrado, a interposição de recurso de apelação contra a sentença que rejeita liminarmente a pretensão do autor, sendo neste caso, o réu citado para apresentar suas contra-razões. Verifica-se pois, que tais princípios são plenamente respeitados, a seu tempo (BUENO, 2006, p. 196).

Portanto, como acertadamente assevera Bueno (2006, p. 72), com a finalidade de dar primazia à incidência imediata do princípio da razoável duração do processo, bem como ao princípio da economia processual e da isonomia, o legislador infraconstitucional instituiu o julgamento liminar de improcedência dos casos repetitivos, postergando o princípio do devido processo legal e do contraditório para o momento do reexame de sua decisão diante do recurso de apelação interposto pelo autor, viabilizando assim, a otimização do princípio da efetividade da prestação jurisdicional.

Assim sendo, pode-se afirma que 0 art. 285-A do CPC, introduzido pela Lei 11.277/06, em que o legislador cumprindo com a exigência do direito constitucional fundamental do art. 5ạ, LXXVIII da CF, "criou poderoso instrumento de contenção de demanda e de célere solução de controvérsias" (GAJARDONI, 2007, p. 110), garantindo assim, o julgamento dos litígios sem dilações indevidas. 


\section{Conclusão}

Ao término deste estudo, pôde-se verificar que de nada adianta o Estado disponibilizar aos jurisdicionados 0 direito de ação, garantindo assim 0 acesso à Justiça, se 0 exercício da jurisdição não ocorrer de maneira efetiva e adequada, hábil a pacificar com justiça os litígios interindividuais. Efetividade essa, que somente é alcançada com a entrega do direito em um tempo razoável. Para tanto, 0 ordenamento jurídico processual civil conta com 0 instituto do art. 285-A, dentre outros mecanismos de celeridade.

0 artigo 285-A do CPC objetiva solucionar as chamadas "demandas de massa", ou seja, casos idênticos que veiculam idêntica tese jurídica e consequentemente, são as grandes responsáveis pelo abarrotamento e descrédito do Poder Judiciário.

Sendo o julgamento de improcedência, respeita-se o princípio do devido processo legal, do contraditório e da ampla defesa, pois tal sentença demonstra por si só, que, implicitamente, o réu teve acolhido seu pedido de rejeição ao pleito do autor, resultando-lhe em uma vantagem sem ao menos ter integrado ao processo. Como na hipótese do art. 285-A o exercício de tais direitos são postergados, diante da cassação da sentença pelo Tribunal, com a remessa dos autos para o primeiro grau, ser-lhe-á ali garantido o amplo exercício dessas garantias constitucionais.

Ademais, o dispositivo em comento não "engessa" o magistrado, uma vez que não está vinculado às decisões de improcedência proferidas anteriormente no juízo podendo assim, motivadamente, no exercício do juízo de valor diante de cada caso concreto, modificar seu entendimento anterior ou ainda entender que a questão não é unicamente de direito, determinando produção de provas para melhor formar seu convencimento, deixando deste modo, de aplicar o art. 285-A.

A doutrina dominante entende que para que 0 art. 285-A alcance seu fim de modo efetivo, qual seja, proporcionar uma tutela tempestiva (célere), a sentença deve estar de acordo com o entendimento dos Tribunais Superiores, demonstrado através das súmulas ou jurisprudências dominantes, ou, utilizar-se delas próprias como paradigma.

Por todo o exposto no decorrer deste trabalho, conclui-se que 0 art. 285-A do CPC encontra-se perfeitamente de acordo com os princípios constitucionais do processo civil, a saber: princípio da isonomia, da segurança jurídica, do direito de ação, do contraditório e ampla defesa; bem como se amolda acertadamente à nova sistemática do processo civil. 
Ademais, conclui-se que o legislador infraconstitucional ao instituir o julgamento liminar dos casos repetitivos, atendendo ao clamor social e adaptando o processo à realidade atual, visou, por intermédio da supremacia dos princípios, concretizar o direito fundamental da razoável duração do processo, previsto no art. 50, LXXVIII da Constituição Federal, proporcionando desta maneira, uma maior racionalização e celeridade à prestação da tutela jurisdicional, hábil a torná-la tempestiva, adequada e portanto, justa. Em outras palavras, 0 art. 285-A constitui-se, pois, em um importantíssimo instrumento para o julgamento sem dilações indevidas.

\section{Referências}

BEDAQUE, José Roberto dos Santos. Garantia da amplitude de produção probatória. In: CRUZE TUCCl, José Rogério (Coord.). Garantias constitucionais do processo civil. 1. ed. São Paulo: Editora Revista dos Tribunais, 1999. p. 152-168.

BUENO, Cássio Scarpinella. A nova etapa da reforma do Código de Processo Civil, vol.2: comentários às Leis n. 11.276/06, 11.277/06, 11.280/06. 2. ed. São Paulo: Saraiva, 2006.

CAM BI, Eduardo. Julgamento prima facie (imediato) pela técnica do art. 285-A do CPC. Revista dos Tribunais, São Paulo, v. 95, n. 854, p. 52-73, dez. 2006.

CINTRA, Antônio Carlos de Araújo; DINAM ARCO, Cândido Rangel; GRINOVER, Ada Pelegrini. Teoria geral do processo. 19. ed. São Paulo: M alheiros Editores, 2006.

CRUZE TUCCI, José Rogério. Garantia do processo sem dilações indevidas. In: CRUZE TUCCI, José Rogério (Coord.). Garantias constitucionais do processo civil. 1. ed. São Paulo: Editora Revista dos Tribunais, 1999. p. 234-260.

FUX, Luiz. A reforma do Processo Civil: comentários e análise crítica da reforma infraconstitucional do Poder Judiciário e da reforma do CPC. Rio de Janeiro: Impetus, 2006, p.23-28.

GAJARDONI, Fernando da Fonseca. O princípio constitucional da tutela jurisdicional sem dilações indevidas e o julgamento antecipadíssimo da lide. Revista IOB de Direito Civil e Processual Civil, São Paulo, v. 7, n. 45, p. 102-129, jan./fev. 2007.

LEITE, Carlos Henrique Bezerra. Curso de direito processual do trabalho. 6. ed. São Paulo: LTr, 2008.

LUCON, Paulo Henrique dos Santos. Garantia do tratamento paritário das partes. In: CRUZE TUCCI, José Rogério (Coord.). Garantias Constitucionais do Processo Civil. 1. ed. São Paulo: Editora Revista dos Tribunais, 1999. p. 92-95. 
M ONTENEGRO FILHO, Misael. Curso de direito processual civil, volume l: teoria geral do processo e processo de conhecimento. 4. ed. São Paulo: Atlas, 2007.

. Código de processo civil comentado e interpretado. São Paulo: Atlas, 2008.

NERY JÚNIOR, Nelson; NERY, Rosa M aria de Andrade. Código de processo civil comentado e legislação extravagante. 10. ed. São Paulo: Editora Revista dos Tribunais, 20007.

PAVAN, Dorival Renato. Comentários às Leis no 11.187 e 11.232 de 2005 e 11.382 de 2006. 2. ed. São Paulo: Pillares, 2007. p. 84-116.

THEODORO JÚNIOR, Humberto. As reformas do Código de Processo Civil operadas pelas Leis no 11.276 e 11.277, de 07.02.2006, e 11.280, de 16.02.2006. In: THEODORO JÚNIOR, Humberto. As novas reformas do Código de Processo Civil. 2. ed. Rio de Janeiro: Forense, 2007. p. 13-18.

WAMBIER, Luiz Rodrigues; WAMBIER, Teresa Arruda Alvim. Anotações sobre o julgamento de processos repetitivos. Revista IOB de Direito Civil e Processual Civil, São Paulo, v. 9, n. 49, p. 38-45, set./ out. 2007.

WAM BIER, Luiz Rodrigues; W AM BIER, Teresa Arruda Alvim; M EDINA, José M iguel Garcia. Breves comentários à nova sistemática processual civil. São Paulo: Revista dos Tribunais, 2006. v. 2, p. 61-71. 